\title{
The king of dirt: public health and sanitation in late medieval Ghent
}

\author{
JANNA COOMANS* \\ Department of History, University of Amsterdam, Kloveniersburgwal 48, \\ Amsterdam, The Netherlands
}

\begin{abstract}
Taking the office of the coninc der ribauden in Ghent as a case-study, this article reconstructs the enforcement of urban sanitation and preventative health practices during the fourteenth and fifteenth centuries. The coninc managed a wide range of issues perceived as potentially polluting, damaging or threatening to health. Banning waste and chasing pigs as well as prostitutes off the streets, the office implemented a governmental vision on communal well-being. Health interests, as part of a broader pursuit of the common good, therefore played an important yet hitherto largely overlooked role in medieval urban governance.
\end{abstract}

Little is known of a modest but oddly named official in late medieval Ghent, the coninc der ribauden. This 'king of the ribalds' oversaw an equally curiously named group of minions or companions (cnapen or gesellen), who collectively were called the 'king's children' (conincxkinderen). Ghent's historians have characterized this official as a factotum who served the city's magistrates along with his minions as a sort of general support, anywhere assistance was needed. ${ }^{1}$ Hans van Werveke described the peculiar coninc as 'endowed with, among other things, responsibility for urban sanitation', ${ }^{2}$ while Charles Diericx remarked as early as 1815 on his strong resemblance to the Roman curator viarum or operum publicorum. ${ }^{3}$ And indeed, there is a notable parallel with street officials in thirteenthand fourteenth-century Italy, who worked to protect urban health by performing a wide array of supervisory tasks. ${ }^{4}$ Likewise, the tasks of

* I would like to express my gratitude to Guy Geltner, Richard Calis, Kim Overlaet and the members of the Centrum for Stadsgeschiedenis at the University of Antwerp for their helpful comments and suggestions.

${ }^{1}$ F. de Potter, Gent, van den oudsten tijd tot heden: geschiedkundige beschrijving der stad, 8 vols. (Ghent, 1883-1901), vol. I, 375.

2 H. van Werveke, De Gentsche stadsfinancien in de Middeleeuwen (Brussels, 1934), 224-47; M. Boone, 'Openbare diensten en initiatieven te Gent tijdens de late Middeleeuwen (14de15de Eeuw)', in L'Initiative publique des communes en Belgique: fondements historiques (Ancien Régime): actes Colloque international, Spa, 1-4 sept. 1982 (Brussels, 1984), 71-114.

${ }^{3}$ C. Diericx, Mémoires sur la ville de Gand (Ghent, 1815), 535.

${ }^{4}$ G. Geltner, 'Healthscaping a medieval city: Lucca's Curia viarum and the future of public health history', Urban History, 40 (2013), 395-415. 
the coninc and his helpers gain a striking coherence when seen from the perspective of preserving the city's communal well-being.

As urban officials roaming the city, they were responsible for policing streets and waterways, co-ordinating sanitation, assisting in military operations as well as public works, manning the fire brigade and participating in civic ceremonies. While the sources rarely reflect on the motivation behind measures or their perceived inter-relation, a picture of spaces and objects, including certain people and animals, that urban authorities perceived as potentially polluting, damaging and putting communal health at risk emerges from the coninc's set of tasks. These tasks fit into a spectrum of issues that local authorities assumed responsibility and jurisdiction over in the name of the common good (ghemenen oirbair). This often-used concept in late medieval Netherlandish sources entailed a range of interventions to preserve peace, safety, prosperity and law. ${ }^{5}$ While scholars of medieval Europe have increasingly recognized the importance and influence of this concept in urban governance, one aspect, namely communal health interests, has remained relatively obscured.

Recent debates on the emerging field of the history of pre-modern public health, as discussed in more detail below, indicate the need to move beyond a narrow focus on medical institutions and epidemic crises. Nor do we have to wait for the emergence of separate urban health offices or central refuse collection services, but rather attention has shifted to broader prophylactic policies and agents working to improve sanitation, broadly defined here as all efforts to clean streets and waters and fight hazardous pollution to prevent disease and secure infrastructural viability, including military and fire safety. While rules aiming to protect or improve communal health can be gathered from a wide range of (printed) prescriptive sources, the more challenging reconstruction of routine enforcement still largely awaits investigation in local archives. In other words, important questions on the means that policy-makers employed to implement health policies remain to be answered. This is especially true for the fourteenth and fifteenth centuries, spanning the Black Death, which has traditionally been viewed as a point of instigation of urban governmental preventative interventions. ${ }^{6}$

Although Ghent's office of the coninc and his minions was in certain ways rather remarkable, and its activities particularly well documented, their function was also illustrative for the implementation of sanitary policies in medieval cities. Taking the evolution of this office as a casestudy, this article aims to reconstruct practices of urban sanitation and preventative health supervision in an era that is still typically thought

${ }^{5}$ E. Lecuppre-Desjardin and A.-L. Van Bruaene (eds.), De Bono Communi: The Discourse and Practice of the Common Good in the European City (13th-16th C.) (Turnhout, 2010).

${ }^{6}$ Most influentally formulated in G. Rosen, A History of Public Health (New York, 1958), 62-70; C.M. Cipolla, Public Health and the Medical Profession in the Renaissance (Cambridge, 1976), but also resonating in D. Porter, Health, Civilization and the State: A History of Public Health from Ancient to Modern Times (London, 1999), 30-45. 
of as lacking any such interventions. It argues that urban officials with tasks related to public health were a permanent presence in late medieval Netherlandish cities, and that communal health interests therefore played a role in municipal governance that has been largely overlooked in urban historiography. Public health policies, as part of a broader pursuit of the common good, impacted the relations between local urban authorities and their subjects, including the perception and negotiation of public and private spaces and subsequent sanitary responsibilities. This study thus challenges the dismissive assessement of the enforcement of hygienic rules and the contention that municipal sanitary organization in the Low Countries began in early modernity, and demonstrates their nature and development during the late medieval era.

Parallels of urban sanitary management in the Low Countries, and across late medieval Europe, have hitherto remained largely unnoticed in general historical urban studies. Besides a focus on regulation rather than practice, two factors have shaped this lacuna. First, sanitary outfits have left no records produced by themselves predating the early modern period. Therefore, their activities remain difficult to reconstruct, contributing to the view of the early modern period as an era of innovation in municipal concerns about sanitation, indeed about public health. While some historians have acknowledged that such groups of sanitary officials may have been in place much longer, the evolution of their offices over the fourteenth and fifteenth centuries remains to be explored in depth. ${ }^{7}$ Secondly, these officials often performed a wide array of tasks, which makes them different from and less distinct than later, more specialized, sanitary and health-promoting outfits. Taking local variations into account, officials working to improve communal health in the late medieval Low Countries had an important general characteristic: they were multitaskers. Making efficient use of a relatively small group of officials, urban magistrates set up municipal sanitation as fluid and dynamic organizations, adaptable to the various challenges facing their communities. This tendency can be summarized as the flexibility model.

That Ghent offers a particularly rich case-study might come as no surprise, given that this was an extraordinarily large and politically dominant city during the late Middle Ages. Its size, with around 60,000 inhabitants before the Black Death and a population fluctuating around 40,000 between 1360 and 1500, generated myriad infrastructural and health challenges. At the same time, interventions in the name of communal well-being reflected the interest of an influential governing

\footnotetext{
${ }^{7}$ W. Pottier and P. Maclot (eds.), 'n Propere tijd!? (On)leefbaar Antwerpen thuis en op straat (1500-1800) (Antwerp, 1988); P. Poulussen, Van burenlast tot milieuhinder: het stedelijk leefmilieu, 1500-1800 (Kapellen, 1987); F. Huisman, 'Stadsbelang en standsbesef: gezondheidszorg en medisch beroep in Groningen 1500-1730', Erasmus University Rotterdam Ph.D. thesis, 1992, 14-29. See also M. van der Heijden et al. (eds.), Serving the Urban Community: The Rise of Public Facilities in the Low Countries (Amsterdam, 2009).
} 
elite, seeking to retain control over and presence in the city. ${ }^{8}$ Further, the visibility of public health practices heavily depends on the survival of archival sources, which situation is particularly favourable for Ghent. Combining evidence extracted from a wide range of local records, especially the extensive series of municipal accounts (stadsrekeningen) and publicly announced decrees (voorgeboden), makes it possible to follow the coninc and conincxkinderen, as 'boots on the ground', in their endeavours to police and sanitize their environment. ${ }^{9}$ The sources reveal neither a static office with a clearly outlined and stable set of officials and activities, nor a linear process, but rather a fluid and dynamic organization, adaptable to the various challenges facing Ghent's late medieval urban community. The sections below first briefly outline the broader context of medieval urban public health and the existence of similar officials elsewhere, and discuss the coninc's origins and jurisdictions. We then trace the outfit's activities and its development over the course of the fourteenth and fifteenth centuries, and conclude with a reflection on the long-term evolution of the office.

\section{Pre-modern public health: definitions, debates and agents}

That we can indeed speak of pre-modern public health has been established by a growing historiography challenging the view of the Middle Ages as a period of indifference towards communal health and its threats. Perceptions diverged from modern Euro-American conceptions, as they were based on Galenic and Hippocratic medical theories that considered stench as a direct cause of air corruption and disease, but also closely associated physical with spiritual health. ${ }^{10}$ Yet much like modern nation-states, late medieval municipalities recognized the promotion of population health as socio-economically and politically beneficial, indeed as a prerequisite for survival of their respective communities. Research therefore can be extended both chronologically and topically. Carole Rawcliffe's monograph on medieval England, for instance, advocated a broadly defined public health, including routine improvement of the physical environment, while Guy Geltner

${ }^{8}$ For recent overviews, see M. Boone and G. Deneckere (eds.), Gent: stad van alle tijden (Ghent, 2010); D. Nicholas, Medieval Flanders (London, 2014).

${ }^{9}$ For the period 1280-1389, I have used the following editions of the Stadsrekeningen: J. Vuylsteke, Gentsche stads- en baljuwsrekeningen 1280-1336 (Ghent, 1900); N. De Pauw and J. Vuylsteke, De rekeningen der stad Gent. Tijdvak van Jacob van Artevelde 1336-1349, 3 vols. (Ghent, 1874-85); A. Van Werveke, Gentse stads- en baljuwsrekeningen 1351-1364 (Brussels, 1970); D. Nicholas and W. Prevenier, Gentse stads- en baljuwsrekeningen (1365-1376) (Ghent, 1999); J. Vuylsteke, De rekeningen der stad Gent. Tijdvak van Philips van Artevelde 1376-1389 (Ghent, 1893). I will hereafter use abreviated titles: e.g. Rek. Gent 1280-1336. When the accounted year straddled two calender years, as did Ghent's schepenjaar, in the footnotes I have referred to that year by the first date (e.g. $1327-28=1327)$.

${ }^{10}$ C. Rawcliffe, Urban Bodies: Communal Health in Late Medieval English Towns and Cities (Woodbridge, 2013), 4-11. See also 'The history of public health in pre-industrial societies: a bibliography compiled by G. Geltner and J. Coomans' (online publication). 
transferred to a medieval context the idea of healthscaping, defined as all 'physical, social, legal, administrative and political process[es] of providing [urban] environments with the means to safeguard and improve residents' wellbeing. ${ }^{11}$ Recent contributions have furthermore refuted earlier narratives of progress or improvement of population health in Europe over the long term, which dovetail with criticism on sociological views of an increasingly 'civilized' western society. ${ }^{12}$ Instead, some scholars have related health policies to the rise and expansion of the state. From this perspective, public health was regarded as a disciplining tool of authorities over their subjects, justifying governmental inventions in the physical environment and daily life. ${ }^{13}$ Taking on this wide definition of public health and the notion that health-promoting practices are intertwined with (spatial) claims to power and authority offers a meaningful context for understanding the multifaceted nature and socio-political impact of the work of Ghent's coninc and his brigade, and similar officials in other Netherlandish cities.

Studies on medieval public health, with a particular focus on England and Italy, but also exploring Germany, France, Iberia and Scandinavia, demonstrate that the numerous extant by-laws on sanitation issued by local urban authorities were no hollow threats or hopeless ambitions. ${ }^{14}$ Zooming in on the understudied Low Countries, together with northern Italy, one of the most urbanized regions in Europe in this period, it becomes clear that here too policy-makers were aware that governing communal health required the instalment of mechanisms of enforcement. Records from Ypres seem to be the earliest testimonies that Netherlandish cities appointed officials to sanitize and supervise certain spaces, as they

${ }^{11}$ Her definition entailed further 'the control of dismissible disease,...provision of water and food of good quality and in sufficient supply, the provision of medical care and the relief of disability and destitution'. Rawcliffe, Urban Bodies, 4-5; Geltner, 'Healthscaping a medieval city', 396. See also Porter, Health, Civilization and the State, 4; idem, The History of Public Health and the Modern State (Amsterdam, 1994), 4-5.

12 C. Fraser Brockington, A Short History of Public Health (London, 1956); N. Elias, The Civilizing Process (Oxford, 1978); G. Vigarello, Concepts of Cleanliness: Changing Attitudes in France since the Middle Ages (Cambridge, 1988). For a critical discussion, see G. Geltner, 'Public health and the pre-modern city: a research agenda', History Compass, 10 (2012), 231-45.

13 Porter, The History of Public Health and the Modern State, 5. See on biopower G. Burchell et al. (eds.), The Foucault Effect: Studies in Governmentality (Chicago, 1991), and its application in medieval studies G. Geltner, Healthscaping Medieval Italy: A Study in Biopower (forthcoming).

${ }^{14}$ Rawcliffe, Urban Bodies; L.J. Skelton, Sanitation in Urban Britain, 1560-1700 (London, 2015); D. Jørgensen, 'Cooperative sanitation: managing streets and gutters in late medieval England and Scandinavia', Technology and Culture, 49 (2008), 547-67; T.F. Glick, 'Muhtasib and Mustasaf: a case study of institutional diffusion', Viator, 2 (1971), 59-81; J.-P. Leguay, La pollution au Moyen Âge dans la royaume de France et dans les grands fiefs (Paris, 1999); D. Balestracci, 'The regulation of public health in Italian medieval towns', in $\mathrm{H}$. Kùhnel et al. (eds.), Die Vielfalt der Dinge (Vienna, 1998), 345-57; A. Kinzelbach, 'Infection, contagion, and public health in late medieval and early modern German imperial towns', Journal of the History of Medicine and Allied Sciences, 3 (2006), 369-89; Geltner, Healthscaping Medieval Italy, ch. 5, offers a synthesis across regions, including the near Middle East. 
document in 1280 , for instance, that a fine for the disposal of filth could be 'collected by the mud officials, each in his station'.$^{15}$ This short reference suggests three things, which, as we will see, are typical for governmental sanitary efforts. First, there were several of these mud officials; second, they were regularly stationed in various places in town; and, third, they generated income by prosecuting environmental offences. Moreover, as in Ghent, such a presence of sanitary officials, and indeed of enforcement of health rules, corresponds with payments noted in local accounts rolls, such as to the overseers of fresh-water supply (pipemestres) and to cleaners around the town hall and the central markets. ${ }^{16}$

But while evidence for Ypres' officials precedes many others, they were by no means the only ones. Such officials dot the late medieval Low Countries, under various names and titles, some of which explicitly invoked tasks of handling refuse and transporting manure. For instance, so-called 'dung carriers' (moosmeiers) were active in Antwerp, ${ }^{17}$ and the similarly named meuderaars or moerknechten, formed Bruges' waste collection brigade and transported manure to the farmers in the city's surroundings. Both were first attested in the fifteenth century, which is typical for many of such officials and municipal workmen. ${ }^{18}$ From 1405 on, moddermeiers and scavengers appeared in urban records in Brussels, as well as officials tasked with cleaning the city's fresh-water system, who were also present in Ypres and Damme. ${ }^{19}$ Further, so-called 'waste citizens' (slijkburgers) in fifteenth-century Utrecht were both policing and cleaning specific places in town in return for citizenship, which were similar to arrangements made in Den Bosch. ${ }^{20}$ To the north-east, the town of Deventer also hired sanitation supervisors and workmen transporting refuse from a number of economically and politically important locations from the fourteenth century on. ${ }^{21}$ The so-called hovelingen van de schutten enforced environmental and market regulation in Groningen at least

$15 \mathrm{~J}$. de Smet, 'Les keures inédites du plus ancien livre de keures d'Ypres', Bulletin de la Commission Royale, 94 (1930), 443. Extant evidence from thirteenth-century Italy and Iberia slightly precedes the first documentation from the Low Countries. Geltner, 'Healthscaping a medieval city'.

16 G. des Marez and E.H. de Sagher (eds.), Comptes de la ville d'Ypres de 1267 à 1329 (Brussels, 1909), 184 (1304), 285 (1308), 338 (1310).

17 Poulussen, Van burenlast tot milieuhinder, 36-43.

18 B. Debaenst, 'Historische stront op Vlaamse grond. Een inleidende studie in de historische faecologie', University of Ghent MA thesis, 1999.

${ }^{19}$ B. Vannieuwenhuyze, "'Allen dengenen die in der stad dienste sijn": Een overzicht van de stedelijke openbare ambten en diensten in het laatmiddeleeuwse Brussel 1229-1477', University of Ghent MA thesis, 2002, 183-6; A. Viaene, 'De pijpemeesters van Ieper', Biekorf, 63 (1962), 280-1.

20 C. Kwakman, 'Slijkburgers in Utrecht', Madoc, 19 (2005), 167-74; B. van den Hoven van Genderen, 'De vieze en ongezonde Middeleeuwen?', in R. Meens and C. van Rhijn (eds.), Cultuurgeschiedenis van de Middeleeuwen: beeldvorming en perspectieven (Zwolle, 2015), 25560; B.C.M. Jacobs, Justitie en politie in 's-Hertogenbosch voor 1629 (Assen, 1986), 146-7.

21 T.A. Spitzers, 'Archaeological evidence and models on waste-disposal and the infrastructure of Deventer', in M. Gläser (ed.), Lübecker Kolloquium zur Stadtarchäologie im Hanseraum IV: die Infrastruktur (Lübeck, 2004), 119-21. 
from 1497 on. ${ }^{22}$ Lacking colourful names but equally important were municipally appointed cleaners in Louvain and Haarlem. ${ }^{23}$ These and other sanitary servants were often assigned to specific places, but their organization could be complemented by public works officials, such as street pavers, or a broader waste collection service. Moreover, other representatives such as city messengers could adopt sanitary chores, as well as perform inspections. In sum, public health policies in medieval towns, although at times strikingly similar, were the outcome of local historical processes, in which negotiations between various stakeholders and the specific demands of local topography - urban infrastructure and the surrounding countryside - all played a role. With these contexts of a broadly and politically defined public health and the existence of similar officials elsewhere in mind, let us proceed to urban sanitation in Ghent.

\section{The coninc's origins and tasks}

Late medieval Ghent had multiple 'kings', as noble titles could be used for various leaders or officials, mimicking hierarchical relations, perhaps with ironic undertones. ${ }^{24}$ The word ribaud likewise had several meanings. The name could arguably originate in the coninc's task as supervisor of ribauden, meaning vagabond and whoremonger. Such a characterization seems to have been apt for certain officials in late medieval France and Italy called roi de ribaud or roi de ribaldi, who also managed municipal brothels. However, since Ghent's records do not use the word in that sense, the more neutral meaning of workman or porter seems more probable. ${ }^{25}$ Like the office itself, the name further evolved during the fifteenth century. While in 1406 the accounts still mention him as coninc van den rebauden, from 1436 he is commonly the 'king of the children' (coninc van den kindren). ${ }^{26}$ Around 1500 , the name had morphed into one directly referring to their task of

22 Huisman, 'Stadsbelang en standsbesef', 16.

${ }^{23}$ However, Leiden did not commonly employ a scavenger. A. van Steensel, 'Het personeel van de laatmiddeleeuwse steden Haarlem en Leiden, 1428-1572', Jaarboek voor Middeleeuwse Geschiedenis, 9 (2006), 191-252; R. van Uytven, 'Stedelijke openbare diensten te Leuven tijdens het Ancien Régime', in L'initiative publique, 21-43.

24 Ypres' pipemestres were in Latin the comitibus dulcis aque. This city furthermore occasionally paid a similarly named compte de ribaud. Marez and Sagher (eds.), Comptes, 41, 126, 159.

25 Middelnederlands Woordenboek (MNW), http://gtb.inl.nl/iWDB/search?actie=article $\& w d b=M N W \& i d=46187 \& l e m m a=$ ribaut, accessed 13 June 2017; J. Haemers and B. Verbist, 'Het Gentse gemeenteleger in het laatste kwart van de vijftiende eeuw: een politieke, financiële en militaire analyse van de stadsmilitie', Maatschappij voor Geschiedenis en Oudheidkunde te Gent, 62 (2008), 313. See also Stadsarchief Gent (SAG), Nota's Van Werveke, no. 1112; A. Terroine, 'Le roi des ribauds de l'hôtel du roi et les prostituées parisiennes', Revue historique de droit français et étranger, 56 (1978), 253-67; F. Viltart, 'Le roi de ribauds a la fin de Moyen Âge: une royaute infame?', in T. Hilltmann (ed.), Les 'autres' rois: études sur la royauté comme notion hiérarchique dans la société au bas Moyen Âge et au début de l'époque moderne (Munich, 2010).

26 SAG, 400, no. 11, fol. 123r (1406), no. 15, fol. 103r (1436), no. 16, fol. 310v (1446), no. 18, fol. 291r (1456), no. 27, fol. 23v (1476). 
handling waste: the king of dung (moorkoning) with his 'dung children' (moorkinderen). ${ }^{27}$

Recent scholarship has suggested that the coninc and his companions were originally a paramilitary corps, who had settled permanently in Ghent in the early fourteenth century, while maintaining some of their earlier functions. ${ }^{28}$ My survey largely confirms this, although the development was not a gradual shift but rather a switching back and forth. The coninc and his minions routinely managed tasks related to health and sanitation, yet at times of war or political crisis they reassumed their military functions and joined expeditions. In the first decade of extant accounts (1314-24), an anonymous coninc is mentioned in the lists of compensations for urban officials, while in 1325 he is commonly referred to by surname and full title. ${ }^{29}$ In contrast to later years, in these first two decades the coninc still appeared irregularly in the annual salary listings, but he did help to move sand and debris around for street paving and in 1314 received payment for 'cleaning the streets of the city', which indicates that waste management and infrastructural viability were part of the coninc's tasks from very early on. ${ }^{30}$

Although we lack sources offering a coherent job description, Ghent's public ordinances outline some of the coninc's and coninxkinderen's jurisdictions. They were increasingly awarded with the privilege of imposing and collecting fines. A decree from 1349, for example, forbade all citizens from carrying their domestic refuse to places that were not allowed, or relieving themselves on the Plaetse (Figure 1), for which prosecution was farmed out to the coninc. From 1350 (repeated in 1366 and 1372), the latter could also collect a fine from anyone who let their pigs roam the streets - and confiscate the animals. ${ }^{31}$ During the fourteenth century, the fines for these and other sanitary offences varied from $5 \mathrm{~s}$. to around 3 l., with the exception of bringing pig manure to the Steendam (Figure 1), which carried a staggering fine of $10 \mathrm{l}$., 'and forfeiture of the dung'. The evidence renders it difficult to discern any clear hierarchy in offences or spaces, as different levels of fines for the same transgressions were decreed over the decades. Yet during the early fifteenth century, penalties for illegal disposal seem to have risen to a standard of 3 and even $51 .{ }^{32}$ At any rate, even the lower sum of 5 s. was equal to a few days' salary

${ }^{27}$ Fris' edition of the anonymous chronicle Dagboek van Gent van 1447 tot 1470, 2 vols. (Ghent, 1901), mentions several conincs: a 'coninc van den kinderen', vol. I, 14; 'Pieter Leyns, coninc van der moorheren', vol. I, 251 (1452); 'Jacop de Bruyne, conynck van Moorkinderen', vol. II, 267 (1491).

${ }^{28}$ Haemers and Verbist, 'Het Gentse gemeenteleger', 313.

${ }^{29}$ Rek. Gent 1280-1336, 68, 424, 588, 643, 887.

30 Ibid., 83. On public works, see ibid., 208-25, 385, 390.

31 N. de Pauw, De Voorgeboden der stad Gent in de XIVe eeuw (1337-1382) (Ghent, 1885), 52, $94,112,124,149$.

32 Ibid., 92 (1366), 114 (1372),149 (1377), 153 (1378); SAG, Voorgeboden 108/2, fols. 22r, 26v. 


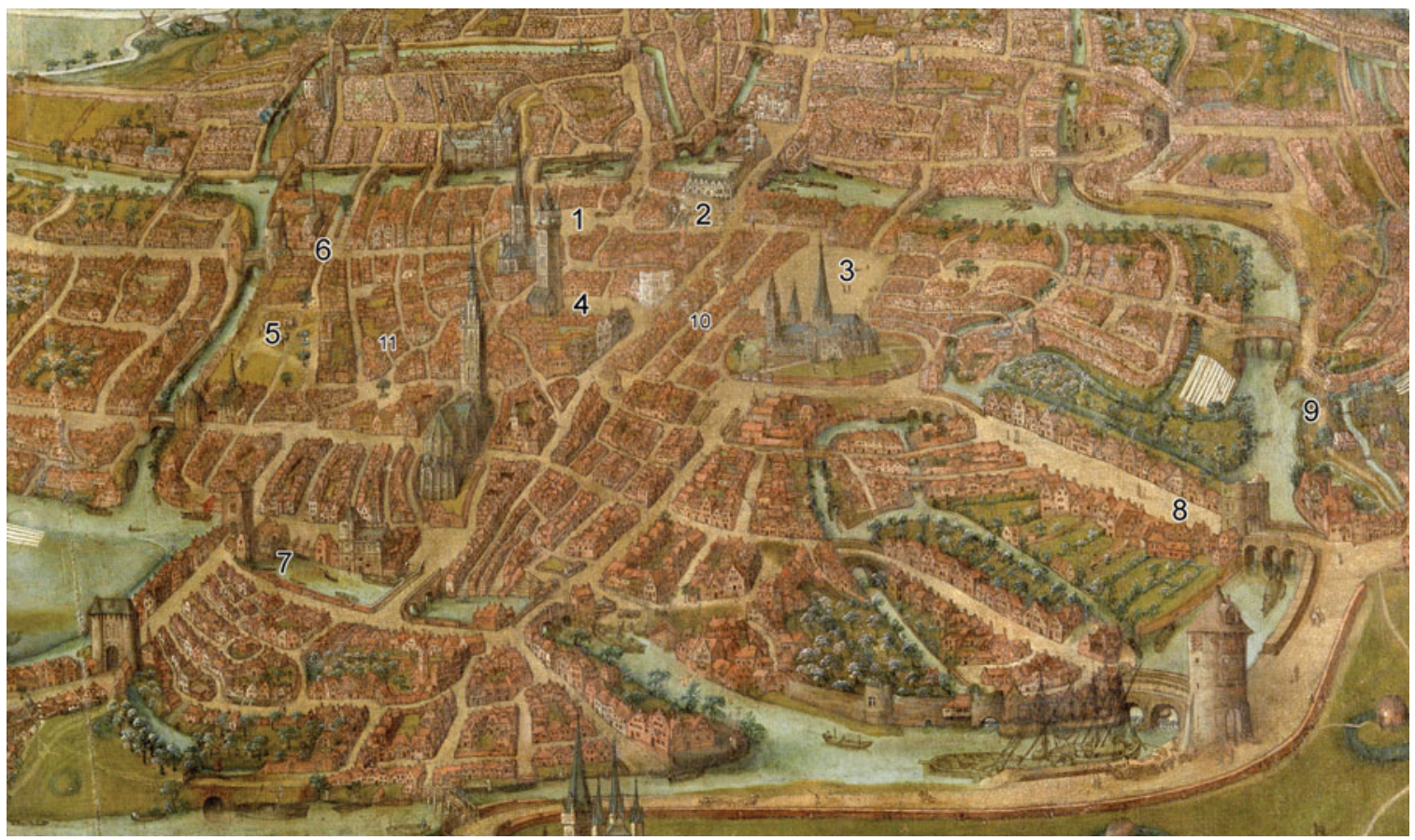

Figure 1: (Colour online) Locations of cleaner-supervisors in Ghent. 1. Korenaard, 2. Vismarkt, 3. Vrijdagmarkt, 4 . Plaetse, 5. Kouter, 6. Walmere, 7. Molen, 8. Steendam, 9. Reke, 10. Werengarenstraat [1540 instruction], 11. Paddenhoek [1540 instruction]. Birds' eye view on Ghent, 1534. STAM Gent (c) www.lukasweb.be. Photo by Hugo Maertens. Indications of cleaners' locations added by the author. 
for a workman, while any fine more than a few pounds would have meant a severe financial blow for most residents. ${ }^{33}$

The coninc and companions seem not to have operated as a city-wide waste collection service but, in addition to sanitizing and overseeing key infrastructures and spaces, were to enforce the execution of sanitary tasks by others. ${ }^{34}$ In 1373, Ghent's aldermen ordered all inhabitants to bring their waste to 'the designated place between the four poles, under surveillance of the coninc' ${ }^{35}$ The magistrates further commissioned the coninc in 1408 to ensure that residents with aligning properties cleaned the city's rivers - which they on various occasions referred to as 'the city's most beautiful jewel'. The coninc and his men were also to uphold the purification of the grounds (aerde) 'by everyone who benefits from them', as well as the ban on discarding coals or pig excrement or washing intestines in the rivers. ${ }^{36}$ These decrees, in sum, illustrate that late medieval urban authorities seem to have generally held citizens responsible for sanitation and upkeep of infrastructure near their living and working environments and saw the link between the two as crucial. Or rather than a top-down instigation, they may have framed what might have been a new governmental interest to co-ordinate preexisting practices as delegation to citizens, neighbourhoods and other institutions. Caring for a section of streets, quays and even waterways was thus promoted as a communal responsibility to fight pollution in the city.

During a period of plague threat around 1488, several officially designated places for waste disposal existed but they did not completely prevent health risks in the ways the aldermen had intended. Accordingly, they ordered greater obedience to 'prevent the great dangers stemming from the dirt and from the smell of the dung heaps lying in the streets' ${ }^{37}$

33 The standard money of account in Ghent's archival records is the Vlaamse groot ( $\mathrm{gr}$. Vl.) consisting of a pound (l.), divided into 12 schellingen (s.), and 240 penningen (d.). However, Ghent's authorities in decrees noted sums in groten parisis (gr. par.) while in the financial accounts they mostly used the much less valuable groten payments (gr. paym.). The standard ratio between them was 1 l. Vl. $=12$ l. gr. par. $=40$ l. gr. paym., Rek. Gent 1365-1376, xxxi. Thus, a fine of 5 s. gr.par. $=5 \mathrm{~d}$. gr. Vl., a large fine of $10 \mathrm{l}$. gr. par. $=200 \mathrm{~d} . \mathrm{gr}$. Vl. In Ghent, in the 1320s, a digger or mason's servant earned around 1,4 d. gr. Vl. per day, and in Bruges in 1363, around 3 d. gr. W. Blockmans and W. Preventier, 'Armoede in de Nederlanden van de $14 \mathrm{e}$ tot het midden van de 16e eeuw: bronnen problemen', Tijdschrift voor Geschiedenis, 88 (1975), 506.

${ }^{34}$ De Pauw, De Voorgeboden, 13, 23, 25, 39, 41, 44, 91, 92, 108, 112, 114, 124, 145, 128, 153, 156; SAG, Voorgeboden 108/2, fol. 75v (1420).

35 De Pauw, De Voorgeboden, 124.

36 'De rivieren binnen der stede tscoenste juweel', De Pauw, De Voorgeboden, 99; repeated in SAG, Voorgeboden 108/2, fols. 50v, 67v. 'Item dat men int ghelike de haerde al omme doe rumen te coste van den ghene die de selve haerde orboren sullen', SAG, Voorgeboden $108 / 2$, fol. 13v.

37 'Omme te stuwene de grote dangieren die commen mochten vanden vulicheyde ende stanck commende uuten messinghen liggende up weghen ende straten', SAG, Voorgeboden 93/26, fol. 11v. 
The reference to the dangers of dung heaps reflects the fear of waste and stench as a health issue, which the coninc was expected to prevent. Since they were in charge of containing various sorts of dirt, miasmatic corruption and other indirect disease threats, it is no surprise to encounter the conincxkinderen in other plague regulations as well. In 1489, for example, they had to police central squares, the meat hall and the fish market to prevent plague patients and those who had been in contact with them from mingling with the crowds. ${ }^{38}$ Although evidence for this specific task dates no earlier than the 1480s, their efforts to curb the spread of disease were coherent with earlier duties relating to disease prevention, and furthermore concerned locations that were already under their supervision for a very long time.

The broad range of the coninc's responsibilities extended to what could be called forms of moral pollution, thus illustrating a diverging conception of how to govern communal health compared to contemporary western views. The coninc gained jurisdiction over the management of groups and individuals perceived as a threat to the city's social order and public morality. He was to ensure in 1349 that no prostitutes should wander on the Plaetse after sunset, or near the Veebrug, under the penalty of losing their overgarment. ${ }^{39}$ Such duties relate to the responsibility for policing foreign poor, which the city gave to the coninc in the early fifteenth century, as discussed further below.

The coninc and his minions did not operate in a vacuum, and the jurisdictions outlined above brought them into contact with other policing agents, such as city servants (garsoenen) and messengers, but also more military-styled groups of officials, of which Ghent's aldermen had an unusually high number at their disposal. ${ }^{40}$ For instance, the conincxkinderen were entitled to a part of the levied fine when reporting transgressions made by fish vendors, yet the market inspectors and the city's messengers could detect and prosecute offences as well indeed, policing the cleanliness of the fish market fitted into a broader range of health concerns regarding food trades. ${ }^{41}$ The conincxkinderen thus likely competed with other officials to obtain revenues from such fines, and in doing so promoted magistrates' desire to expand their authority over commercial spaces, which included concerns for sanitation and health. On the other side of the spectrum, the coninc's brigade performed various menial tasks. They therefore resembled workmen such as street pavers and porters and related to others active in urban sanitation. ${ }^{42}$ In fact, late medieval cities seem to have often had very

\footnotetext{
38 SAG, Voorgeboden 93/26, fol. 14r.

39 De Pauw, De Voorgeboden, 44.

${ }^{40}$ De Potter, Gent, vol. I, 369-91; Haemers and Verbist, 'Het Gentse gemeenteleger'; Boone, 'Openbare diensten', 82.

41 The other parts were divided between city and count. SAG, Voorgeboden, 108/2, fols. $8 \mathrm{r}$ (1405), 10r (1406); Voorgeboden 93/26, fol. 2r (1483).

42 Van Werveke, De Gentsche stadsfinancien, 242-3.
} 
diverse - though difficult to identify - groups of agents active in waste collection. Guilds were endowed with sanitary responsibilities around their work spaces, of which the meat business has been explored in the most detail. ${ }^{43}$ Yet Ghent's authorities also awarded St John's Hospital with the right to manage the livestock market (Veemarkt), which included the task of 'keeping the market clean' ${ }^{44}$ We can find similar examples elsewhere in the Low Countries: the greengrocers in Gouda had the exclusive right to collect waste in their carts, and in seventeenth-century Amsterdam the magistrates delegated waste collection and its revenues to the poor orphanage. ${ }^{45}$ Furthermore, Ghent's financial accounts contain a few indications that the city might have outsourced domestic waste collection. We see an investment in carts in 1338 made 'to clean the streets in all parishes and purify the grounds' - but these do not reappear in the accounts. ${ }^{46}$ This suggests that such a waste-collection service continued independently of governmental support, or simply did not last for long.

In sum, Ghent's aldermen assigned the coninc and his helpers with tasks designed to preserve the traversability of streets, squares and waterways. Further, the specific places mentioned in these decrees were not all in the city's centre, but included some located in its periphery, such as gated entrances and docks, and correspond with payments to conincxkinderen to clean and supervise them regularly (see below). These locations with economic, civic, military importance were deemed particularly relevant for the common good and their sanitation beneficial for communal health. At the same time, health interests confirmed or strengthened the public nature of this network of spaces. Their intended role was to prevent pollution and obstruction by waste or goods, animals and even unwanted individuals - chasing pigs as well as prostitutes off the streets - and thus designating them as a threats to communal well-being. It also suggests a perceived connection between physical and spiritual forms of dirt or, to use Mary Douglas' adage, as matter out of place: both rejected elements in an ordering system. ${ }^{47}$ We gain an even clearer view of the multifaceted nature of their activities when tracing the activities the city government documented in its financial accounts.

43 N. Ciecieznski, 'The stench of disease: public health and the environment in late-medieval English towns and cities', Health, Culture and Society, 4 (2013), 91; E.L. Sabine, 'Butchering in mediaeval London', Speculum, 8 (1933), 335-53; Rawcliffe, Urban Bodies, 241-83.

44 'Dat sij de plaetse van den veemaerct sullen houden reine', De Potter, Gent, vol. VII, 141, 146; F. van de Putte, 'Het Sint-Jan-Ten-Dullen Hospitaal in het laatmiddeleeuwse Gent', University of Ghent MA thesis, 2007, 182.

45 L.M. Rollin Couquerque and A. Meerkamp van Embden (eds.), Rechtsbronnen der stad Gouda (The Hague, 1917), 241 (1510); J.E. Abrahamse, De grote uitleg van Amsterdam: stadsontwikkeling in de zeventiende eeuw (Bussum, 2010), 296-7.

46 Rek. Gent 1336-1349, vol. I, 340, 349, 399.

47 M. Douglas, Purity and Danger: An Analysis of Concept of Pollution and Taboo (London, 2003), 44. 


\section{Practices and following coninc Lanenman}

Financial records help us to move beyond the perspective of what the coninc and his servants were entitled or ideally supposed to do. Between 1314 and 1382, not a year went by without payments to them, amounting to over 500 entries. While the work for which the coninc received annual wages remains unspecified, the many chores paid for separately reveal important aspects of their routines. The sums paid to them in the fourteenth-century accounts can be grouped into seven types, and tell us much about his health-related duties de facto. In descending order of frequency, these were, first, clothing and salary, usually of $10 \mathrm{l}$. paym. Whether they had a distinct uniform remains unclear; they received a summer and winter outfit, variously referred to as gambeson (waerdecose) and later more often as overcoat (froc), made of striped cloth or, as one entry noted, a yellow fabric made 'of the city's wool'. ${ }^{48}$ Secondly, the city authorities paid for sanitation, including an increasing number of conincxkinderen supervising specific locations. The coninc as well as his servants also often worked as messengers, and participated in military operations - transporting equipment and repairing infrastructure around Ghent. A fifth type of activity, namely public works, also included cleaning and transporting debris. ${ }^{49}$ The carts they were in charge of, mentioned in many of the entries in the accounts, could thus be used for military operations as well as moving and removing materials for the city's construction projects. ${ }^{50}$ Further, urban governments across the Low Countries regarded improving fire safety and the organization of firefighting as one of their central tasks. Indeed, clean streets and accessible waterways enabled adequate responses to rising flames and therefore improved fire safety. Ghent's accounts routinely list compensations for those who helped to carry water, including to the coninc and minions, and for residents whose homes had to be torn down to prevent fire from spreading, as well as for extinguishing equipment. ${ }^{51}$ While the coninc is mentioned explicitly as in charge of fire safety during the sixteenth century, his involvement in firefighting as well policing hazardous structures is also evident two centuries earlier. ${ }^{52}$

As a final category, the accounts contain recurring references to compensations for the coninc and his companions' efforts concerning civic

48 'Waerdecose': Rek. Gent 1280-1336, 391, 887; Rek. Gent 1336-1349, vol. III, 294; Rek. Gent 1351-1364, 330; 'Geluwen froclakene vander stede wulle', Rek. Gent 1336-1349, vol. I, 455; 'Froc': Rek. Gent 1351-1364, 104, 297, 567; Rek. Gent 1365-1376, 17.

49 Rek. Gent 1280-1336, 217 (1321). See also ibid., 225 (1322); Rek. Gent 1351-1364, 578, 594, 656; Rek. Gent 1376-1389, 145 (1379).

50 See for instance Rek. Gent 1280-1336, 242 (1337); Rek. Gent 1336-1349, 340 (1338); Rek. Gent 1351-1364, 241 (1355-56).

51 Rek. Gent 1280-1336, 122, 266, 609-10, 622, 717; Rek. Gent 1351-1364, 120. In 1378, the aldermen ordered 100 buckets, as attested by both a public decree and an entry in the financial accounts. Rek. Gent 1376-1389, 95; De Pauw, De Voorgeboden, 150.

52 Rek. Gent 1336-1349, vol. II, 90, 142, 440, vol. III, 108; Rek. Gent 1351-1364, 486; Rek. Gent 1365-1376, 26, 152; Haemers and Verbist, 'Het Gentse gemeenteleger', 313. 
rituals. ${ }^{53}$ Most notable was their participation in Ghent's delegation to the procession of the Flemish communes at the cathedral of Tournai, a religious event that simultaneously served to consolidate political bonds. ${ }^{54}$ With a group of between five and seven minions, they annually provided practical support as well as joined the rite, starting in 1339 and with few exceptions throughout the fourteenth and fifteenth centuries. ${ }^{55}$ They also helped and guarded during another core civic tradition, namely the night watch procession (Auweet) at the middle of Lent. ${ }^{56}$ In addition, during more incidental festivities such as jousts and inaugurations, they provided logistical support and sanitized the locations. ${ }^{57}$ Besides being of practical help, it also suggests that they were integrated into ceremonies celebrating civic identity, order and well-being on a more spiritual level. Furthermore, ceremonies in town provided a stimulus to the enforcement of street sanitation. City heralds were paid to proclaim cleaning instructions to inhabitants, and the coninc and his consorts could impose a $5 l$. fine if residents of the streets through which the Auweet procession would pass did not remove their filth. ${ }^{58}$

To explore further the flexible tasks of a fourteenth-century coninc in Ghent, we can trace the activities of Janne Lanenman, who held the job for nearly a decade, between 1339 and 1348. Lanenman started his career with a busy year. As usual, he received his wages as well as a doublet made of striped cloth. ${ }^{59}$ While four of his servants were paid to clean around the town hall and three market squares, Lanenman delivered letters and goods as a messenger, arrested two men and kept watch over them during the two days they were pilloried, and participated with seven companions in the procession of Our Lady of Grace in Tournai. ${ }^{60}$ Political upheaval then pushed the coninc towards military tasks. Dressed in a new frock coat, he accompanied a party to Kortrijk with the count of Flanders, and

53 The coninc and minions also occasionally helped to guard within the city, often for a few nights, or during special occasions and festivities. Rek. Gent 1280-1336, 77; Rek. Gent 13361349, vol. I, 9, 99; Rek. Gent 1376-1389, 103.

54 P.J. Arnade, Realms of Ritual: Burgundian Ceremony and Civic Life in Late Medieval Ghent (Ithaca, NY, 1996), 56-7.

55 Rek. Gent 1336-1349, vol. I, 382 (1339); Rek. Gent 1351-1364, 296, 326, 413, 514, 565; Rek. Gent 1365-1376, 16 , 39, 62, 100; Rek. Gent 1376-1389, 372; SAG, Stadsrekeningen, no. 11, fols. 25v (1401), 302v (1411), no. 13, fol. 325r (1426), no. 15, fol. 68v (1436), no. 16, fol. 311r (1446), no. 18, fol. 260r (1456), no. 25, fol. 111r (1466), no. 27, fol. 23v (1476), no. 29, fol. 172r (1486).

56 Alfons van Werveke, 'Het Auweet, de groote parade van Halfvasten vóór 1540', Bulletin der Maatschappij der Geschied- en Oudheidkunde te Gent, 15 (1907), 213; Rek. Gent 1365-1376, 25, 71, 118, 139; Rek. Gent 1336-1349, vol. I, 219-20; SAG, Stadsrekeningen, no. 11, fols. 136r (1406), 315r (1411), no. 13, fol. 340r (1426), no. 15, fol. 109r-v (1436), no. 16, fol. 340v (1446), no. 18, fol. 309r (1456), no. 25, fol. 158v (1466), no. 29, fol. 242r (1486).

57 Rek. Gent 1336-1349, vol. II, 134; Rek. Gent 1365-1376, 48, 117-18; Rek. Gent 1376-1389, 34.

58 SAG, Stadsrekeningen, no. 11, fol. 315r-v (1411); SAG, Voorgeboden 108/2, fols. 51r, 63r, 65v; Arnade, Realms of Ritual, 61-3. See also E. Lecuppre-Desjardin, 'Grote schoonmaak in de stad', Jaarboek voor Ecologische Geschiedenis (2002), 19-35.

59 On the Plaetse, Korenaard, Vismarkt, and Vrijdagmarkt, Rek. Gent 1336-1349, vol. I, 395.

${ }^{60}$ Ibid., vol. I, 382, 391, 432, 433, 454. 
made preparations for military actions. For the latter task, Lanenman joined forces with former coninc Muglin and 26 others, who left the city to repair the roads and inspect the city's carts. ${ }^{61}$ He repeated this task to enable quick transport for soldiers and equipment for 30 days in $1342 .{ }^{62}$ In 1340, a political conflict between Ghent and Tournai culminated in a military confrontation. With an unusually large number of 33 companions, Lanenman 'laboured with great effort' to transport the carts. They were collectively rewarded with nearly $500 \mathrm{l}$. for 80 days' work. This was a large sum compared to the annual standard salaries per person, yet a minor expense in the total war cost of $80,990 l .{ }^{63}$ Moreover, while the coninc and his companions took up care for infrastructure and transport, six physicians offered on-site medical assistance. ${ }^{64}$

A key player in this military confrontation was Jacob van Artevelde, who together with Edward III of England took part in the siege of Tournai in 1340. This implies that Van Artevelde employed the coninc for political ends. However, the office of the coninc far precedes his reign, and the coninc and consorts should not be confused with his small private army. ${ }^{65}$ Moreover, while Van Artevelde was murdered in 1345 and many of his allies in Ghent's urban government were replaced, coninc Lanenman retained his position. ${ }^{66}$ The stability of the office suggests its integration as an enforcer or preserver of the public good in the eyes of Ghent's governing elites, beyond a particular political faction. Back in Ghent, Lanenman punished a 'mad woman' (dullen wive) by 'binding her' over the river Schelde for two hours (perhaps on a cucking stool), and later put her in St John's Hospital, which functioned as an institution for the mentally ill since the early fourteenth century. ${ }^{67}$ The siege of Tournai did not create permanent hostilities between the cities, as the next year Lanenman again joined Ghent's delegation at the religious procession there, while also clearing the Vrijdagmarkt of dung for local festivities in the city. ${ }^{68}$ Finally, in 1347 he rounded up 13 companions and went out on the streets to 'destroy ovens and furnaces and pull out the May trees'. ${ }^{69}$ While the latter seems to have been connected to clearing the streets after the maypole festivities, the former task related directly to fire prevention, as did making ice holes in the frozen rivers (loemen hiewen) in winter, a task

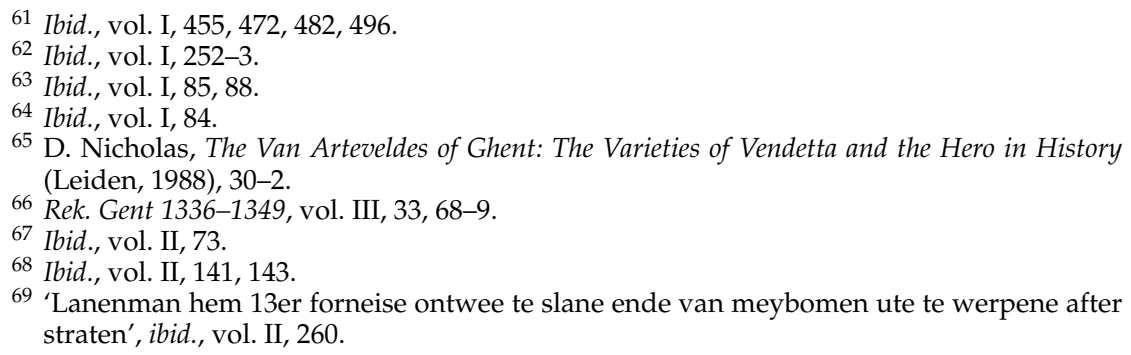


coninc Lanenman performed with the help of nine companions - which suggests their activities changed along with the seasons. ${ }^{70}$

In sum, Lanenman and his conincxkinderen were assigned an ostensibly eclectic set of tasks, subject to change in times of upheaval and war, yet focused on protecting and maintaining urban order, safety, infrastructural flow and sanitation. Since the development of municipal sanitation has often been regarded as a response to plague epidemics, it is striking that all these endeavours took place before the onset of the Black Death in 1348. The variety in tasks at first sight may undermine an interpretation of these officials as advocates of communal health. However, in light of the flexibility model noted above, we might regard it as demonstrating a dynamic perception of health risks and how communal well-being could be practically pursued in the eyes of late medieval urban authorities.

\section{The conincxkinderen: Ghent's sanitation brigade}

Urban sanitation formed a cycle shaped by socio-economic and environmental forces, and did not necessarily require intervention of or instigation by municipal authorities to function. But several reasons made it relevant for governing agents to associate themselves with it. From a Galenic perspective, bad odours created by excrement, domestic waste or industrial residues corrupted the air, and therefore potentially made the population ill. Local authorities thus intervened when private interests, such as residents looking for affordable housing or crafts and industries seeking easy and cheap waste disposal methods, clashed with communal needs - or at least the needs of political elites - for a clean, healthy and accessible urban environment, with unobstructed roads, gutters, pipes and waterways. Another incentive for governmental co-ordination was that waste, especially manure, had value, and money could be made by exploiting it. The demand varied according to soil types and arable activities in the surrounding countryside, and is likely to have been considerable in Ghent. ${ }^{71}$ Another economic incentive was the revenue from fines for environmental offences. Yet perhaps even more important than generating income was the fact that managing sanitation and health issues, as part of governing the common good, had value as a tool to govern or discipline and establish authority over the city.

That this political claim dovetailed with sanitary efforts and health concerns is demonstrated by the conincxkinderen, who were appointed

${ }^{70} \mathrm{Ibid}$., vol. I, 431. See also on this practice M. Ryckaert, 'Brandbestrijding en overheidsmaatregelen tegen brandgevaar tijdens het Ancien Régime', in L'initiative publique, 249-52.

71 S.S. Morrison, Excrement in the Late Middle Ages: Sacred Filth and Chaucer's Fecopoetics (New York, 2008), 151; Debaenst, 'Historische stront'; E. Thoen, Landbouwekonomie en bevolking in Vlaanderen gedurende de late Middeleeuwen en het begin van de Moderne Tijden (Ghent, 1988); R.M.R. van Oosten, De Stad, het vuil en de beerput: De opkomst, verbreiding en neergang van de beerput in stedelijke context (Leiden, 2015). 
as cleaner-supervisors and each assigned to a specific location. ${ }^{72}$ From occasional workers during the early fourteenth century, their numbers expanded to two to five annually paid cleaners. ${ }^{73}$ This part of the sanitary organization further developed after 1360. The Plaetse and Vrijdagmarkt were persistently central targets, augmented by the Vismarkt (the fish market and great meat hall), the Kouter (1361-62), the Watermolen, the Steendam and the Korenaard (the grain market), which added up to a total of seven hired cleaners in 1365, nine in 1366 and between nine and ten until 1376. At that point, crisis again interceded with sanitary practices, as the city engaged in intensive political conflicts and expenses were largely confined to war efforts.

Visualized in Figure 1 are all 10 locations assigned to municipal cleaners in these decades. These places were of political, social and economic importance, essential nodes in an infrastructural network: markets, waterways and urban entrances and squares aligning municipal buildings, located both in the city's centre and its periphery. Moreover, these places also contained the city's few public wells, which were created and maintained with municipal funds. Commercial and economic motivations seem to have informed their selection, but the most and longest supervised location, the smaller Plaetse (present-day Botermarkt), housed one of Ghent's two Aldermen's Houses (the Schepenhuis van de Keure), and was thus above all a politically charged space, together with the Vrijdagmarkt symbolizing as well as staging urban identity and independence. ${ }^{74}$

The appointed cleaners did not only target specific places; these tasks were also executed by specific persons. It suggests the importance of a regular face representing the regime rather than just a uniform. For instance, one Staeskin de Kersmakere maintained the Plaetse continuously for nearly 20 years (1362-80), ${ }^{75}$ and Pieter Orchies supervised the Korenaard between 1338 and 1345. However, the latter also went on a journey to deliver a letter to the pope in Avignon in 1339. He even got robbed on the way back, but was repaid for his misfortune. Moreover, because of his long absence that year, his wife received some small alms. ${ }^{76}$ Pieterkin den Dievel, cleaner of the Walmere, died while being on the road in service of the city and therefore the aldermen paid for his funeral. ${ }^{77}$ Finally, the length of their careers and the possibility of promotion is

72 The total group of conincxkinderen receiving annual payment comprised never more than 10 men, but their numbers grew considerably when military activities intensified.

${ }^{73}$ Rek. Gent 1280-1336, 606 (1328).

${ }^{74}$ F. van Tyghem, Het Stadhuis van Gent (Brussels, 1978); M.C. Laleman and G. Vermeiren, 'Ruimte en bebouwing in het centrum van het middeleeuwse Gent', Handelingen der Maatschappij voor Geschiedenis en Oudheidkunde te Gent, 64 (2010), 26-30, 38; M. Boone, 'Urban space and political conflict in state medieval Flanders', Journal of Interdisciplinary History, 32 (2002), 621-40.

75 Rek. Gent 1351-1364, vol. I, 570, vol. II, 19, 41, 65, 92, 112, 134, vol. III, 25, 85, 243.

76 Rek. Gent 1336-1349, vol. I, 281, 395, 436 (trip to Avignon), 455 (alms), vol. II, 30, 110, 199, $397,467$.

77 Ibid., vol. II, 199 (1342), 467 (1345). 
illustrated by a certain Gossin Knesselare, who first appeared in the lists of payments in 1335 for cleaning the Plaetse. He held this job for five consecutive years, perhaps even longer - he was likely among the unspecified group of companions assisting coninc Janne Lanneman in his endeavours discussed above. ${ }^{78}$ In 1343, the city even donated a house to Gossin for his efforts, while 14 years later we encounter an entry for $24 \mathrm{l}$. of overdue wages to 'Gossine, the coninc, who previously was a city servant' ${ }^{79}$

The phrase 'keeping clean' or 'having kept clean' shows the continuous nature of the cleaners' appointment to one location, where they assumed double roles of enforcer-supervisor and cleaner-collector. The supervisory role of the concincxkinderen is evident in the term versien or verwaren, which translates as supervising, policing, protecting or guarding, and highlights the multifaceted nature of their work as well as their routine - though likely not permanent - physical presence in these spaces. ${ }^{80}$ The coninc's and minions' modest wages as compared to those of some other officials, and their reimbursements for separate tasks, suggests that this was not a full-time job. The $10 \mathrm{l}$. paid annually was the lowest wage of all contracted urban officials. For example, the long-term employed street paver earned around $25 l$; the two surveyors, who played a major role in both public works and more domestic construction activities, received $48 \mathrm{l}$. each; and a city physician received between 60 and $80 l^{81}$ The conincxkinderen were likely only present on certain (market) days, and during other days performed their various additional tasks. Moreover, like many other officials, they had additional sources of income, such as from incidental tasks and levied fines.

The day wages for the coninc and his minions varied from $1 \mathrm{~d}$. $\mathrm{gr}$. per day in the first half of the fourteenth century to around 3-5 $d$. gr. during the late fourteenth and early fifteenth centuries. Thus, the $10 \mathrm{l}$. paym. that a coninc's minion received for cleaning-supervising a certain square equalled wages for anywhere between 20 and 60 days. ${ }^{82}$ As for their socio-economic profile, when payments in kind, such as clothing, and for additional tasks are taken into account, the coninc and his brigade earned a sum that likely put them well above the lowest social echelons. One entry even documents a payment to the conincxkinderen 'for creating a draft or

78 Rek. Gent 1280-1336, 994; Rek. Gent 1336-1349, vol. I, 46, 164, 281, 395, vol. II, 30 (1340).

${ }^{79}$ SAG, Jaarregisters van de Keure, Reeks 301, no. 1, fol. 9r (1343); 'Item Gossine, den coninc, die voertijts was der stede cnape', Rek. Gent, 1351-1364, 382 (1357).

${ }^{80}$ Examples of these phrases: Rek. Gent 1280-1336, 330; Rek. Gent 1336-1349, vol. I, 164; Rek. Gent 1351-1364, 333.

81 Rek. Gent 1336-1349, vol. I, 44 (1336). Physician Arnoud van der Leene would serve the city for over 40 years; Rek. Gent 1280-1336, 80, 83, 249, 590, 888; Rek. Gent 1336-1349, vol. II, 108,300 .

$82 \mathrm{See}$ n. 33 on the different currencies and wages. $10 \mathrm{l}$. gr. paym. $=60 \mathrm{~d} . \mathrm{gr}$. Vl. References on the coninc's day wages: Rek. Gent 1280-1336, 390; Rek. Gent 1336-1349, vol. I, 490, vol. III, 444; Rek. Gent 1376-1389, 103, 128, 197; SAG, 400, no. 11, fol. 320v (1411). 
cost evaluation (bewerpe) of the works' ${ }^{83}$ This suggests that at least some were literate and numerate, and at any rate technically skilled and knew what was required to build, maintain and adjust urban infrastructures, as well as to estimate the costs involved. However, they clearly also carried out menial jobs, sometimes with specially designed machinery. ${ }^{84}$

It was, in sum, a stable municipal office. Those cleaner-companions who sanitized the same place for years on end must certainly have been a familiar sight for citizens and market vendors alike. Moreover, the personality and ambitions of individual conincs and conincxkinderen could expand the nature of their work and how they used their jurisdictions. Therefore, they were not only a clear instrument of enforcement of sanitary regulations, but also more generally a physical representation of government in the city, likely recognizable by their uniforms.

Linking these insights to the historiographical debates on the nature of pre-modern public health above, we may conclude that the attitude towards urban sanitation of policy-makers in late medieval Ghent, which may be extrapolated to other Netherlandish towns, encompassed two main aspects or claims. First, authorities wished to sanitize and supervise several key or public spaces by stationed officials such as the conincxkinderen. This also helped to define or designate places as public or falling under direct control of officialdom. Secondly, the complex status of many streets and waterways as publicly accessible but legally private spaces encouraged an official division of sanitary tasks among different agents. Each was expected to take care of a distinct aspect of urban sanitation and infrastructural maintenance - which contribution to communal health was then checked by multitasking officials such as the coninc. Thus, while medieval cities rarely had centrally funded and organized waste collection services, their absence hardly meant that authorities were uninterested in enforcing urban health and sanitation. It suggests that we need to adopt a more inclusive view rather than focus mainly on the instigation or predecessors of such a municipal sanitary office, which has been central in earlier studies.

\section{Developments of the coninc's office}

The tasks of the coninc and his men were subject to significant changes, which illustrates that the development of municipal sanitation hardly traces a linear progression towards centralization. Between 1350 and 1379, sanitary activities as well as investments in public works rose. While their military efforts diminished in this relatively tranquil period, the

83 'Conincxkinderen met bewerpe te makene angaende den wercke', SAG, Stadsrekeningen, no. 14, fol. 342r (1446). See also SAG, Stadsrekeningen, no. 18, fol. 263v (1456).

${ }^{84}$ Such as a new millstone in 1446 with the help of their 'king's rigs' (sconinx engiene). SAG, Stadsrekeningen, no. 14, fol. 342r. See also no. 18, fols. 315r-316r (1456). 
group of conincxskinderen expanded and reassumed them during Ghent's rebellion against Count Louis II of Flanders in 1379-85, joining nearly a dozen military expeditions in new suits of armour. ${ }^{85}$ This conflict also impacted municipal documentation, which became fragmented in the two following decades. In what is left of the city's records for the 1380s and 1390 s, the activities of the coninc or his outfit are barely visible. By 1400, the reimbursements for sanitary supervisors on the squares had vanished completely.

However, the office did not altogether disappear. Both coninc and servants still received clothing, but the city reduced their wages. ${ }^{86}$ The focus of the coninc's tasks shifted in the early fifteenth century to assisting in public works, a role that expanded further during the 1420s and remained a standard part of their activities until the end of that century. ${ }^{87}$ Judging by the payments per month, it provided the coninc and companions with their main source of income and must have kept them occupied most of the year. For example, in 1336, the conincxkinderen earned a total of $10,135 d$. gr. for public works. In 1498, they collectively received $9,324 \mathrm{~d}$. $\mathrm{gr}$. This amounts to an average of around 30 day wages per week, which had to be distributed among the group - perhaps around 10 persons working a little over 14 days a month. ${ }^{88}$ It fits into a broader investment in public works, which on average took up 7.7 per cent of the city's annual funds. ${ }^{89}$ In addition, the city gave the coninc and his helpers small alms, including peat and wine, while also using them to deliver alms that the city donated to various institutions such as hospitals, monasteries and guild houses. ${ }^{90}$

Governmental interest in regulating the presence of unemployed strangers and foreign beggars increased considerably during the fifteenth century, reflecting a growing concern throughout the Low Countries. ${ }^{91}$

85 Rek. Gent 1376-1389, 128, 193, 197, 204, 248-98; D. Nicholas, The Metamorphosis of a Medieval City: Ghent in the Age of the Arteveldes, 1302-1390 (Lincoln, NB, 1987), 9.

86 Clothing cost commonly between 6 and $8 l$. for the conincxkinderen collectively, out of the total of $c .260 l$. the city annually spent on cloth for officials. SAG, Stadsrekeningen, no. 11, fols. 32v-34r (1401), 131v-132v (1406), 310r-312r (1411), no. 13, fol. 34v (1426-27), no. 15, fol. 97 (1436), no. 16, fols. 331v-332r (1446), no. 18, fols. 287r, 288v, 291r (1456), no. 25, fols. 134r, 136r (1466), no. 27, fol. 39r (1476), no. 29, fol. 210r (1486).

87 SAG, Stadsrekeningen, no. 11, fols. 131v-314v. From the 1420s, the conincxkinderen are included in every month in the sections for public works: no. 13, fol. 341r-v (1426), no. 15, fols. 103r, 111r-v (1436), no. 16, fols. 314v, 342r-343v (1446), no. 25, fols. 310-12 (1456), no. 27, fols. 64r-67v (1476), no. 29, fol. 243r (1486).

88 SAG, Stadsrekeningen, no. 15, fols. 111r-112v (1436), no. 30, fols. 83r-91r (1498).

89 J. Haemers and W. Ryckbosch, 'A targeted public: public services in fifteenth-century Ghent and Bruges', Urban History, 37 (2010), 215.

${ }^{90}$ Donations for the coninc and minions were usually $20 \mathrm{~d}$. gr. Vl. SAG, Stadsrekeningen, no. 11, fols. 23v (1401), 301v (1411), no. 13, fol. 323r (1427), no. 16, fol. 308r (1447), no. 25, fol. $107 \mathrm{r}$ (1466). Distribution of donations (peat, wine, etc.): no. 18, fols. 263v-264r (1456), no. 29, fol. 220r (1486).

91 A. Boele, Leden van één lichaam: denkbeelden over armen, armenzorg en liefdadigheid in de Noordelijke Nederlanden 1300-1650 (Hilversum, 2013), ch. 8. 
The aldermen limited the time such groups were allowed to stay within the walls to solicit for alms to one day, and threatened offenders with imprisonment and corporal punishment followed by expulsion from the city. They also prohibited gambling in churches and cemeteries, and placed enforcement of both laws in the hands of the coninc. ${ }^{92}$ These decrees, defining a form of social and moral hygiene, corresponded with several payments to the coninc for expelling poor workmen from the city after the torturer $(c o c)$ had administered a beating. ${ }^{93}$ Strikingly, the entries carefully outline that the execution of corporal punishment was not part of the coninc's job. ${ }^{94}$ Moreover, the coninc regularly 'escorted' mentally ill people to St John's Hospital..$^{95}$

In sum, the payments for the coninc and companions shift from cleaning and supervising (market) squares, bridges and quays in the second half of the fourteenth century to appointments mostly as workmen for public constructions in the fifteenth century. At least from 1400 until the early sixteenth century, they were no longer explicitly reimbursed for sanitizing central squares. And while it is certainly possible that previous arrangements continued to exist more independently and without financial support by the aldermen - and therefore likely largely invisible in the municipal records - the fifteenth-century sources do contain fewer investments in sanitary activities. Another possibility, however, is that these changes are the result of shifts in municipal recordkeeping. At any rate, the coninc and companions maintained, perhaps even extended, the jurisdictions to levy fines on matters related to sanitation and social hygiene. Thus, reduced means of investing or less interest in documenting investments in public health did not necessarily mean less interest in regulating citizens' behaviour. Rather, it suggests that the coninc and coninxkinderen were further encouraged to generate income from the fines for sanitary offences and other transgressions discovered during inspections of streets and squares - as well as from selling waste. The fact that they could collect the fine right away implies that written records simply never existed. Moreover, the right of confiscation noted above suggests that the coninc and his minions stored and sold a range of objects, including manure and pigs.

What can explain such a shift? There are few explicit indications that fear of plague or other epidemics played a major role, yet it may have stimulated a sense of importance and urgency to enforce sanitary policies. Nor do demographic changes offer an obvious explanation, as the city's

92 SAG, Voorgeboden 108/2, fol. 62v.

93 SAG, Stadsrekeningen, no. 15, fol. 101r (1436), no. 18, fol. 299r (1456). See also on costs for the administration of justice W. Ryckbosch, Tussen Gavere en Cadzand: de Gentse stadsfinanciēin op het einde van de Middeleeuwen (1460-1495) (Ghent, 2007), 74.

94 SAG, Stadsrekeningen, no. 15, fol. 101r (1436).

95 For example, one person in 1406, four in 1426 and two in 1436. SAG, Stadsrekeningen, no. 13, fols. 338r-339r (1426), no. 15, fols. 103v, 106r (1436). 
population declined during the late fourteenth century and expanded slowly thereafter, if at all. Rather, political unrest and related financial pressure, leading to multiple crises in the late fourteenth and fifteenth centuries, may have at times negatively impacted resources and public health policies. ${ }^{96}$ Thus, local political and economic factors likely impacted not only public health practices but also the discourse and perception of communal well-being.

The coninc's institution within Ghent's government lasted deep into the early modern period, and developed into a separate municipal sanitation and firefighting department. Within this long-term process, the group and its leader also changed their name to moorkoning, who now presided over the moorkinderen or moorknechten. ${ }^{97}$ A decree from 1540, more than two centuries after the first traces of the coninc, outlines their duties in detail. They were still mainly responsible for keeping filth out of the streets, acting as dung and waste collectors, as well as managing two waste disposal sites - and may have sold the manure and debris. The coninc and minions were tasked with cleaning two central streets in particular (see Figure 1), but also had to prevent damage to any buildings, bridges, quays and wells by regular inspections. In keeping with his medieval predecessors' tasks, the early modern coninc oversaw fortifications (stadsvesten), sought to contain roaming animals and manage mentally ill inhabitants. ${ }^{98}$ The 1540 instructions put them in charge of firefighting and related equipment, while also tasking them with janitorial duties at the town hall, including ritual functions of escorting guests into the building - similar to their ceremonial roles in earlier periods. New additions to long-term duties were the tasks of offering unsold wheat on the market for sale the next morning, and constructing the scaffold in case of criminal executions. ${ }^{99}$ A late seventeenth-century ordinance elaborated on their daily routine, and reveals a set of tasks similar to that of the 1540 instruction, but also to early fourteenth-century evidence. The outfit, now reduced to four persons, supervised the Vismarkt and Vrijdagmarkt on Wednesday and Friday, and encouraged vendors to clean up at the end of the day. Two men were permanently stationed near the town hall, which was also the place where they would gather in case of emergency. ${ }^{100}$ Another main task

${ }^{96}$ Marc Boone examines the financial impact of Ghent's conflicts with signorial powers in Geld en macht: de Gentse stadsfinanciën en de Bourgondische staatsvorming (1384-1453) (Ghent, 1990). See also Ryckbosch, Tussen Gavere en Cadzand.

97 A separate archival collection that starts around 1570 contains annual listing and job applications of the moorkinderen. SAG, Reeks 141 (Stadsofficies), no. 183: Koning van de Moorkinderen; no. 184: Moorkinderen. See also Reeks 533 (Stadswerken), no. 173: Moorkinderen.

98 De Potter, Gent, vol. I, 381.

99 Ibid., 378.

100 SAG, Reeks 108, no. 196; E. Floin, 'Vuyligheyd ende onreynigheid: niet-industriele milieuhinder te Gent in de zeventiende eeuw', University of Ghent MA thesis, 1997, 50-2, 85-8. 
was the supervision of the disposal of building debris, which suggests a perpetuation also of their function as public works assistants. ${ }^{101}$

The long-term development of this municipal brigade contains both key continuities and some important shifts. They likewise held remarkably long appointments, often for more than a decade, suggesting a permanent sanitary organization, which to an extent also applies to the fourteenth century. Further examination of their social practices may, however, illuminate continuities and changes in performed activities. Two main differences seem to be the loss of military activities by the mid-sixteenth century, and the fact that they were increasingly expected to consult and negotiate their public health tasks with Ghent's neighbourhood organizations (gebuurten). ${ }^{102}$ This latter development is another example, in addition to the disappearance of cleaners assigned to specific locations after 1379 , contradicting the idea of a linear expansion or centralization of urban sanitation.

\section{Conclusion}

The history of Ghent's coninc illuminates late medieval urban governments' intent in improving their cities' health through sanitation and the preservation of infrastructural flow, challenging the common modern vision of indifference and inadequacy. Although it remains difficult to reconstruct specific discourses on health pertaining to this office, the fact that it embodied this set of tasks suggests a governmental vision of urban health, as part of a spectrum of closely related interests that can be summarized by the concept of the common good. The coninc and his brigade were part of a broader range of agents working, with various tools and incentives, to improve and protect public health, which deserve further investigation. Yet the evidence presented here offers several key insights to the broader debates on public health. First, it demonstrates its practical pursuit in an era far preceding what is often thought to be the starting point of such activities, both in the Low Countries as well as other regions in Europe. Secondly, it suggests that the development of municipal sanitation, ranging from menial chores to policing illegally discarded waste, roaming animals, fire hazards and unwanted inhabitants, was not a linear evolution from merely supervision to centralization. Nor was there a clear break in practices between the medieval era and (early) modernity. Finally, while their combined tasks brought the coninc and conincxkinderen to myriad places in town - and far beyond during military operations Ghent's authorities were mainly positioning them as overseers of a specific set of places. Therefore, health concerns in a broad sense were one factor

101 SAG, Reeks 114, no. 54 (1644). Cited in Floin, 'Vuyligheyd ende onreynheyd', 64.

102 J. Decavele, Gebuurteleven en dekenijen te Gent 14de-20ste eeuw (Ghent, 1992), 17-51; Floin, 'Vuyligheyd ende onreynheyd', 55-8, 91-6. 
shaping the boundaries between public and private spheres, and helping to define the public nature of certain urban spaces. They were thus an important tool to maintain physical governmental presence and routinely enforce the detailed regulation the aldermen issued on many aspects of daily life in the city. 